DETEERINANTS OF LIPID PEROXIDATION [LPO] IN CYSTIC FIBROSIS [CF]

71 B.M.Wink lhofer-Roob (1), B.Puhl(2), D.H.Shmerling (1) A.Krebs(2), It.Esterbauer(2) - Dept of Pediatries, Univ. of Zurich(1), Inst. of Biochemistry, Univ. of Graz(2)

Polyunsaturated fatty acids [PUFAs] of low density lipoproteins [LL] are protected against LFo by vitamin $\mathrm{E}$ and carotenoids. In vitro exposure of LDL to a prooxidant leads to consumption of these antioxidants [AO] (lag-phase $[\mathrm{lag}]$ ), resulting in formation of conjugated dienes $[\mathrm{CD}]$. In $5 \mathrm{CP}$ patients CD generation in LDI. was monitored up to complete LDL oxidation. Lag was measured, $a-$, $\gamma$-tocopherol [T], $\beta$-carotene $[\mathrm{C}]$ and other carotenoids were determined in plasma and LDL. 3 patients showed a short lag $(30,57,60$ $\mathrm{min})$ compared to others $(135,152 \mathrm{~min})$ and to healthy controls, indicating a suboptimal supply of AO. They also had decreased $a-T$ in plasma (median) $(11.0 \mu \mathrm{mol} / 1)$ and LDI. $(1.4 \mathrm{nmol} / \mathrm{mg}) . \beta-\mathrm{C}$ was very low in all patients $(0.08 \mu \mathrm{mo1} / 1)$, as were other carotenoids. The length of the lag was more closely related to LDL $a-T \quad\left(r^{2}=0.84\right)$ than in controls $\left(r^{2}=0.51\right)$, indicating the lack of other $A O$. CD content in fully oxidized LDL was considerably lower in patients (CD absorbance 0.4-0.6) compared to controls (0.8-1.0), suggesting a limited amount of oxidizable PUFAs in IDL. For identical LDL $\alpha-T$ CF patients had a longer lag than controls, despite lower carotenoids. In conclusion, LDL-LPO in CF is almost exclusively preven ted by $a-T$. Low oxidizable purAs in LDL due to essentiul FA deficiency lead to limited CD formation even in severe no deficiency.

EFFECT OF RICE CEREAL FORTIFIED WITH ELLCTROLYTIC IRON ON INFANT IRON STATUS. TOMas Walter Eva Her-

72 trampf, Sandra Bartholmey, Luig Veloso, Giuria peña Fernando Pizarro, (Spon Ricardo Uauy) University o Chile, IN'FA, Santiago, Chile and Gerber Products Co, Fremont MI, USA.

To determine whether cereal fortified with electroytic iron contributes to infant iron nutrition, 3 groups of 100 spontaneously weaned infants (SW) were randomly assigned at 4 mo to 1) formula w/o Fe but cereal w/Fe $(45 \mathrm{mg} / 100 \mathrm{~g})$. 2) formula and cereal w/o Fe (negative control) and 3) formula $\mathrm{w} / \mathrm{Fe}$ (12 mg/1t of $\mathrm{FeSO} 4$ ) and cereal w/o Fe (positive control) Additionally, 200 breast fed (BF) infants were randomized to 4 ) cereal $\mathrm{w} / \mathrm{Fe}$ or 5 ) cereal $\mathrm{w} / \mathrm{o} \mathrm{Fe}$. The targeted cereal consump$t$ ion of 24-30 g/day was reached at 5-7 mo. At 8 and 12 mo groups 1 \& 3 showed significantly better iron status than the negative control (group 2), with no difference between 1 and 3 . Data at $8 \mathrm{mo}$ ( $\quad(*)$ equals p $<.05$ from group 2.

\begin{tabular}{|c|c|c|c|c|c|}
\hline Group & Cereal & Formula & $\underline{H g b}(g / L)$ & $\underline{\underline{x}} \underline{\mathrm{s}}$ & $\mathrm{SF}(x+$ range $\mathrm{SD})$ \\
\hline $1 \mathrm{SW}$ & $+\mathrm{Fe}$ & $-\mathrm{Fe}$ & $* 119 \pm 9$ & $11.4 \pm 6$ & $* 9(4-23)$ \\
\hline SW & $-\mathrm{Fe}$ & $-\mathrm{Fe}$ & $114 \pm 6$ & $10.7 \pm 6$ & $6(2-17)$ \\
\hline$S W$ & $-\mathrm{Fe}$ & $+\mathrm{Fe}$ & $* 121 \pm 8$ & $* 13.7 \pm 7$ & $* 9(4-19)$ \\
\hline
\end{tabular}
The fortified BF group (4) reached significant advantage at 12 ( Hgb $12.2 \pm 0.8 \mathrm{~g} / \mathrm{dl}$ vs $11.7 \pm 0.9 \mathrm{~g} / \mathrm{dl}$, p<.05). Rice ceregl fortified with electrolytic iron consumed at 24 to 30 dail from 4 ro of age provides sufficient bioavailable iron prevent iron deficiency anemia during the first year of life.
EFFICACY OF CARROT-RICE SOUP IN THE TREATMENT OF ACUTE DIARRHEA 74 Beate Pietschnig, Nosheen Javaid, Ernst Schuster,

Department of Pediatrics, University of Vienna, Austria and George Sad Institute, Allama Iqbai
Medical college, Lahore, Pakistan

The treatment of acute diarrhea with glucose- based solutions results in rehydration but does not reduce the severity of diarrhea. Oral rehydration solutions (ORS) based on rice cereal and carrots may reduce stool output and restore fluid volume mor quickly.

In a prospective, randomized study we evaluated the efficacy of a commercial carrot/rice- based ORS A (Na $52 \mathrm{mmol} / \mathrm{L}$ ) and two glucose- based ORS B ( $\mathrm{Na} 55 \mathrm{mmol} / \mathrm{L}$ ) and $C(\mathrm{Na} 90 \mathrm{mmol} / \mathrm{L})$. Fluid intake, fecal and urine output and absorption of fluid was measured in 161 infants and children (3-48 months of age) during measured in 161 infants and children (3-48 months of age) during
the first 48 hours after admission. The number of stools the first 48 hours after admission. The numbur of stools
$(p<0.01)$ and the mean fecal output $(p<0.05)$ per $\mathrm{kg}$ body weight were significantly lower in group $A$. Children in group $A$ also had significantiy $(p<0.01)$ greater fluid absorption (mea $464 \mathrm{ml} / \mathrm{kg})$ than in groups $\mathrm{C}(312 \mathrm{ml} / \mathrm{kg})$ and $\mathrm{B}(140 \mathrm{ml} / \mathrm{kg})$ A carrot/rice- based ORS was effective in the rehydration of infants and children with dehydration due to diarrhea. The solution decreased stool output and promoted greater absorption of fluid than did the two glucose- based solutions.
POSTNATAL METABOLIC ADAPTATION - THE EFFECTS OF GESTATION AND FEEDING.

75

Jane M Hawdon, Mart in P Ward Platt, Albert Aynsley-Green Department of Child Health, University of Newcastle upon Tyne, Newcastle upon Tyne, UK.

Gluconeogenesis and ketogenesis are integral aspects of postnatal metabolic adaptation. This study compared the pre-feed metabolic profiles of 156 term and 62 preterm infants, aged $0-6$ days, with those of 52 older children, to examine the effects of gestation and current feeding practices on these processes.

Preterm infants had lower mean blood glucose concentrations than term infants in the first few postnatal hours $(2.5 \mathrm{mmol} / \mathrm{l}$ vs $3.2 \mathrm{mmol} / 1 ; \mathrm{P}<0.05)$, and levels of gluconeogenic precursors were high at this time. Unlike term infants and older children preterm infants had jow ketone body concentrations, even when blood term infants had low ketone body concentrations, even when blood
glucose concentrations were low. Independently of gestational
age, ketone body concentrations of preterm infants were related to age, ketone body concentrations of preterm infants were related
intake volume of enteral feed. For term infants, blood glucose intake volume of enteral feed. For term infants, blood glucose breast fed infants had lower blood glucose concentrations than formula fed term infants ( 3.6 vs 4.0 mmol/l; $<P 0.05$ ).

Preterm infants appear less able than term infants to utilise gluconeogenic percursors immediately after birth, or mount a keto genic response during the first postnatal week. Enteral feeding of nreterin infants may stimulate maturation of metabolic adaptation.

\section{MALARIA, FEVER AND RESTING ENERGY EXPENDITURE IN GAMBIAN CHILDREN}

73

Nicolas Stettler, Yves Schutz, Jean-Léopold Micheli, Roger Whitehead and Eric Jéquier - Institute of Physiology, University of Lausanne, CH-1005 Lausanne, Switzerland

The aim of the study was to measure the changes in resting energy expenditure (REE) induced by malaria and to assess to what extent they are related to fever and nutritional status.The REE of 19 Gambian children (mean age \pm SEM $=9 \pm 1 \mathrm{yrs}$, weight $24 \pm 2 \mathrm{~kg}$, expected weight for height $86 \pm 1 \%$ ) was measured with a hood system at reped the onset of malaria crisis (test A), 3 to 4 days after therapy (test $B$ ) and 14 to 21 days later (test $C$ ). There was no significant weight loss between $A$, $B$ and $C$. The axillary temperature averaged $39.2 \pm 0.1,36.6 \pm 0.1$, and $36.7 \pm 0.1^{\circ} \mathrm{C}$ in the three tests respectively. REE in test $\mathrm{A}$ was significantly higher than REE in test $B(223 \pm 10$ versus $174 \pm 8 \mathrm{~kJ} / \mathrm{kg}$.day, $p<0.0001)$, but in test $C(169 \pm 8 \mathrm{~kJ} / \mathrm{kg} \cdot d a y)$, it did not differ from the REE observed in test $B$. The relative increase in REE was correlated to the difference in body temperature $(r=0.46, p<0.05)$; the slope of the regression line indicated an equivalent of $6.9 \%$ increase in $\mathrm{REE} /{ }^{\circ} \mathrm{C}$. The individual increase in $\mathrm{REE} /{ }^{\circ} \mathrm{C}$ was correlated to the \% weight for height $(\mathrm{r}=0.54, \mathrm{p}<0.05)$. It is concluded that malaria crisis induced a transient $30 \%$ increase of REE which is promptly normalized if treated. This hypermetabolism was related to both temperature changes and nutritional status.
DETERMINATION OF WHOLE-BODY DEGRADATION RATES OF MRNA

IN VARIOUS MAMMALS BY MEASURING 7-METIYLLUUNINE AND 8-HYDROXY-7-METHYLCUANINE IN URINE G. Schöch*, H. Topp, K. Kikillus, G. Heller-Schöch Forschungsinstitut für Kinderernährung, Dortmund, FRG

We have developed a noninvasive method for determining the whole-body degradation rates of cytoplasnic tRNA, rRNA and mRNA by measuring specific nearly quantitatively excreted modified RNA-catabolites (ribonucleosides, nucleobases) in urine by HPLC. Our aim is to use RNA degradation rates as indicators of the metabolic state in mamnals under metabolic stress. We have found in mamnals of various weights (Schöch $G$ et al (1990) Eur J Clin Nutr 44: 647-658) that at metabolic equilibriun the degradation Nutr 44: 647-658) that at metabolic equilibriun the de
rates of tRNA and rRNA per unit body weight are highly correlated with the basal metabolic rates (BMR) per unit body weight (calculated by the formula: $\operatorname{BMR}\left(\mathrm{kJ} \times \mathrm{d}^{-1}\right)=240$ $\mathrm{kg}$ body weight 0.74 ). We can now show for rats, preterm infants, goats, sheep, human adults and pigs $(0.3-127 \mathrm{~kg})$ that the degradation rates of nRNA also correlate well with the BMR $(r=$ $0.93, p<0.01$ ). The degradation rate of mRNA was deterinined by firstly measuring 7-methylguanine and it's oxidation product 8-lydroxy-7-methylguanine in urine and secondly by subtracting from the total amount the calculable fractions of these catabolites of the degradation of tRNA and rRNA. 